УДК [631.816.12+631.53.48]: $633.11 \ll 321 » .003 .13$

(C) 2015

\author{
Рожкко А. О., доктор сільськогосподарських наук, \\ Чернобай С. В., аспірант \\ (науковий керівник - доктор сільськогосподарських наук А. О. Рожков)
}

Харківський національний аграрний університет ім. В. В. Докучаєва

\title{
ВПЛИВ НОРМ ВИСІВУ ТА ПОЗАКОРЕНЕВИХ ПІДЖИВЛЕНЬ НА ЕФЕКТИВНІСТЬ ВИРОЩУВАННЯ ЯЧМЕНЮ ЯРОГО СОРТУ ДОКУЧАЄВСЬКИЙ 15
}

\section{Рецензент - доктор сільськогосподарських наук В. І. Філон}

У статті представлені результати досліджень, проведених протягом 2012-2014 рр. на дослідному полі ХНАУ ім. В. В. Докучаєва щзодо впливу застосування різних варіантів норм висіву та позакореневих підживлень на варіабельність урожайності зерна ячменю ярого сорту Докучаєвський 15. Встановлено високу економічну та біоенеріетичну ефективність позакореневих підживлень посівів. Найвища врожайність зерна та кращі показники економічної та біоенертетичної ефективності вирощування було одержано на варіантах проведення сівби нормою висіву 5,0 млн насінин/га. Також було доведено, щуо оптимізація норми висіву забезпечує підвищення ефективності позакореневих підживлень.

Ключові слова: норма висіву, позакореневі підживлення, ячмінь ярий, урожайність зерна, економічна та біоенертетична ефективність, собівартість, рентабельність.

Постановка проблеми. Формування високопродуктивних посівів зернових потребує більшого, ніж в інших культур, регулювання цілого комплексу чинників, які визначають високий біологічний та господарський потенціал посівів рослин. Це пов'язано з тим, що протягом вегетації відбувається ріст та диференціація вегетативних і генеративних органів, а також процеси, які зумовлюють не тільки кількість речовини, що виробляється, а й іï розподіл у рослині, зокрема накопичення в органі, що має найбільше господарське значення - зернівці. Тому формування продуктивності слід розглядати одночасно 3 тими чинниками, від яких залежить показник як загальної біологічної продуктивності, так і головної їі частини - врожаю зерна.

Аналіз останніх досліджень і публікацій, у яких започатковано розв'язання проблеми. Численними дослідженнями доведено, що рівень конкурентної боротьби між рослинами у посівах $\epsilon$ ключовим чинником у підвищенні рівня реалізації ресурсного потенціалу їхньої продуктивності $[7,8]$. Єдиної думки стосовно того, за якої густоти стояння рослин можна одержати максимальний врожай не існує і досі. Для 3'ясування проблеми необхідно розуміти процес формування врожаю 3 урахуванням розвитку складових його елементів. Ці процеси протікають порізному залежно від комплексного впливу зовнішніх та внутрішніх чинників.

Сучасні досягнення у селекції на врожайність показують, що чим вищий генетичний потенціал продуктивності рослин, тим більшими можуть бути норми висіву насіння. Очевидно це пов'язано зі структурою посіву, зміною розподілу асимілятів, питомою масою окремих елементів продуктивності, які беруть участь у формуванні врожаю. Підвищення рівня врожайності та покращання якості продукції завжди супроводжується додатковими затратами коштів. Саме тому користь від їхнього застосування залежать не тільки від приросту врожайності, а й від економічної ефективності, яка $є$ важливим показником оцінки доцільності поширення у виробництво елементів технології вирощування, які забезпечують підвищення рівня врожайності [6].

Узагальнюючими показниками економічної ефективності є співвідношення результатів діяльності й витрат на їхнє одержання. Визначальним критерієм економічної ефективності в умовах ринкових відносин $\epsilon$ прибуток у розрахунку на одиницю виробничих витрат, інших виробничих ресурсів [10]. Останнім часом поряд 3 економічною оцінкою все більшу увагу дослідників привертає енергетична оцінка ефективності технологій вирощування різних сільськогосподарських культур, окремих агрозаходів і т. п. [9]. У теперішній час така оцінка являється універсальною і дає змогу порівнювати енергоємність певних агрозаходів у різних умовах $[1,2,4]$. Цей підхід дає можливість дати кількісну характеристику енергетичної ефективності. Система біоенергетичних показників більш стійка, що надзвичайно важливо в умовах вільного ціноутворення, ін- 


\section{СІЛЬСЬКЕ ГОСПОДАРСТВО. РОСЛИННИЦТВО}

фляційних процесів, зміни курсів валют і т. п. Зрозуміло, що біоенергетичний підхід не може замінити економічний, проте він дає більш різносторонню, об'єктивну оцінку ефективності вирощування [5]. Інтенсифікація сільськогосподарського виробництва та підвищення врожайності супроводжується збільшенням біоенергетичних витрат, у тому числі й за рахунок удосконалення технології вирощування культури. Через це потрібно розробляти енергоощадні технології вирощування, за яких буде витрачатися менше енергії.

Мета досліджень полягала в удосконаленні технології вирощування ячменю ярого 3 метою більш повного розкриття генетичного потенціалу зернової продуктивності рослин ячменю ярого.

Завдання досліджень: визначення комплексного впливу норми висіву та позакореневих підживлень на рівень реалізації генетичного потенціалу зернової продуктивності посівів ячменю ярого сорту Докучаєвський 15, обгрунтування оптимальних варіантів досліджуваних технологічних елементів 3 точки зору економічної та біоенергетичної ефективності.

Методика досліджень. Дослідження проведено протягом 2012-2014 pр. на дослідному полі ХНАУ ім. В. В. Докучаєва на базі восьмипільної зернопаропросапної сівозміни кафедри рослинництва за загальноприйнятою методикою [3].

Ділянками першого порядку були такі варіанти норм висіву: 4,0; 4,5; 5,0 і 5,5 млн насінин/га. Ділянками другого порядку були такі варіанти позакореневих підживлень посівів у фазу трубкування: 1 контроль (без підживлень); 2 - «Кристалон особливий» (доза внесення - 1,5 кг/га); 3 - «Реаком-СРзерно» (доза внесення - 5 л/га); 4 - «Кристалон особливий» + «Агро ЕМ»; 5 - «Реаком-СР-зерно» + «Агро ЕМ». Доза внесення біопрепарату «Агро ЕМ» становила 10 л/га.

Облікова площа посівної ділянки досліду -30 м². Кількість повторень у досліді - чотириразова. Загальна кількість ділянок у досліді - 80. Дослід закладено методом розщеплених ділянок у два яруси. Грунт дослідного поля - чорнозем типовий важкосуглинковий на карбонатному лесі. В орному шарі грунту міститься 4,4-4,7\% гумусу, рухливого фосфору (за Чириковим) - 138 мг/кг, калію - 103 мг/кг грунту. Місце досліджень має характер нестабільного зволоження. Кількість опадів за вегетацію у 2012, 2013 і 2014 рр. становила відповідно 252,4, 217,1 та 263,9 мм за середньобагаторічного показника - 241,0 мм.

Температурний режим вегетаційного періоду у роки проведення досліджень особливо у 2013 році характеризувався значним підвищенням рівня цього показника порівняно із середньоба- гаторічними даними. Встановлені перевищення температурного режиму вносили значні корективи на хід росту і розвитку рослин, формування їх зернової продуктивності, у той же час це дало змогу надати більш повну, об'єктивну оцінку впливу досліджуваних технологічних елементів на формування врожайності зерна.

Результати досліджень. У проведених дослідженнях встановлено високий вплив досліджуваних елементів технології на мінливість зернової продуктивності посівів ячменю ярого. У середньому за три роки досліджень максимальною урожайність зерна була за норми висіву 5,0 млн насінин/га - 2,49 т/га (див. рис.).

За проведеними статистичними розрахунками показники врожайності зерна залежно від впливу норми висіву належали до різних гомогенних груп. Зі збільшенням норми висіву прибавка врожайності зерна поступово зменшувалася. Зокрема, найбільший приріст урожайності зерна відзначено зі збільшенням норми висіву з 4,0 до 4,5 млн насінин/га 0,15 т/га (6,7 \%), у разі підвищення норми висіву 3 4,5 до 5,0 млн насінин/га урожайність зростала на 0,10 т/га (4,2 \%). Зі збільшенням норми висіву з 5,0 до 5,5 млн насінин/га відзначено зменшення врожайності зерна на 0,08 т/га або (3,3 \%).

Згідно $з$ проведеним статистичним аналізом з використанням рангового критерію Уоллєра-Дункана було виділено чотири гомогенні групи показників урожайності зерна залежно від впливу позакореневих підживлень посівів полімерними добривами i біопрепаратом «Агро ЕМ». Максимальна статистично достовірна прибавка врожайності зерна ячменю ярого сорту Докучаєвський 15 порівняно 3 контролем досліду була на варіантах сумісного застосування полімерних добрив - «Кристалону» i «Реакому» разом із біопрепаратом «Агро ЕМ» - відповідно 2,43 і 2,41 т/га. Порівняно з варіантами одноосібного застосування «Кристалону» $\mathrm{i}$ «Реакому», врожайність зерна на варіантах сумісного їх застосування із біопрепаратом «Агро ЕМ» зростала на 0,04 т/га (2 \%) (див. рис.). Розрахунки біоенергетичної ефективності вирощування ячменю ярого за різних варіантів норм висіву та позакореневих підживлень посівів у фазу трубкування свідчать про високу ефективність цих агрозаходів (табл. 1). У середньому за три роки досліджень, коефіцієнт енергетичної ефективності (Кее) вирощування ячменю ярого найвищим був за норми висіву 5,0 млн насінин/га3,53 одиниці. Значне зростання Кее за умови проведення сівби цією нормою висіву зумовлювалося вищим показником акумульованої енергії врожаєм за практично рівнозначних витратах непоновлюваної енергії. 


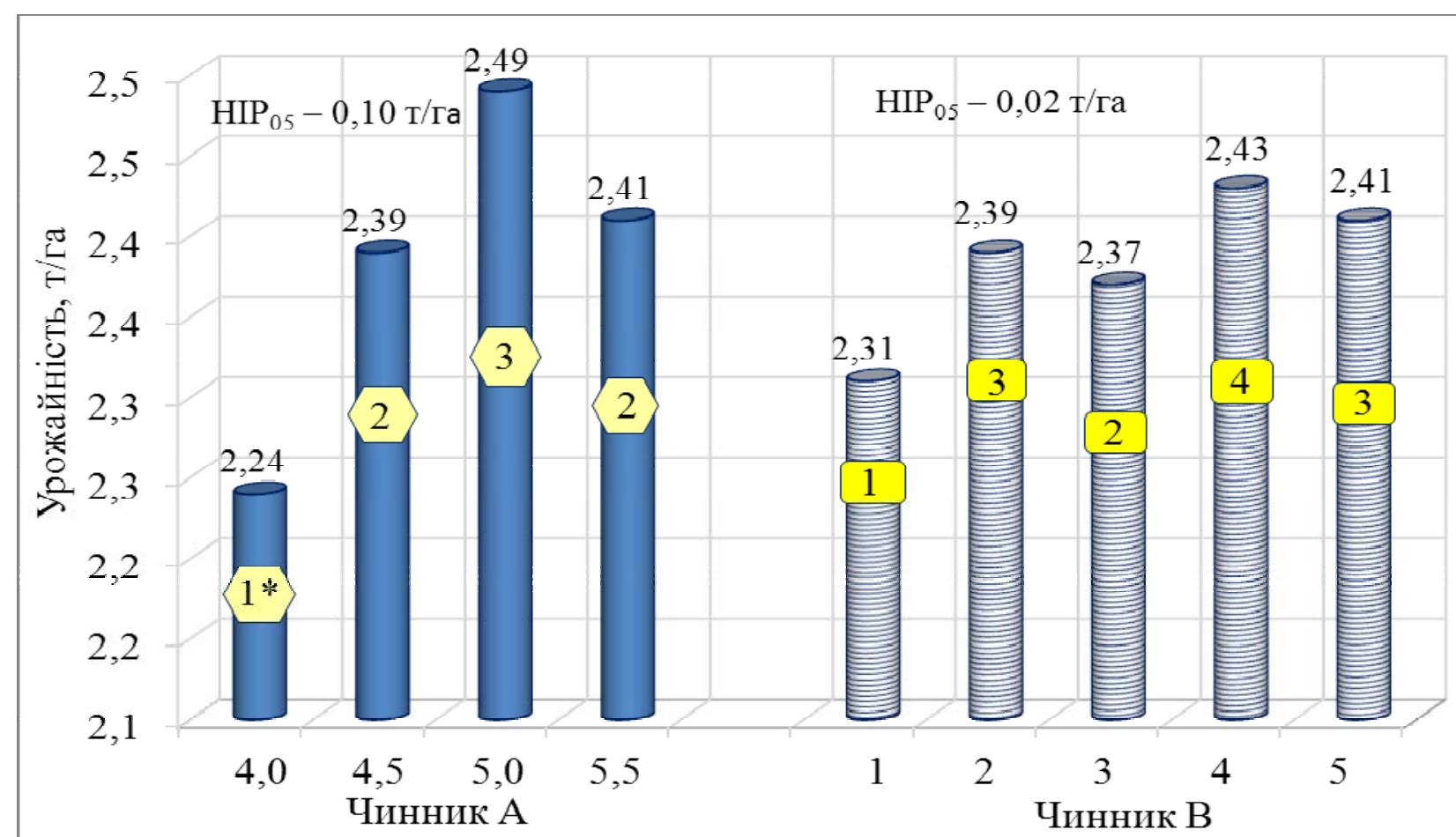

Рис. 1. Урожайність зерна ячменю ярого сорту Докучаєвський 15 за впливу норм висіву (чинник А) та позакореневих підживлень (чинник В), т/га. Середнє за 2012-2014 рр. Умовні позначення: * - рангові групи: I перша; II - друга; III - третя; IV - четверта. Варіанти підживлень: 1 контроль; 2 - крист.; 3 - реаком; 4 - крист. + агро ЕМ; 5 - реаком + агро ЕМ.

Порівняно з варіантами, на яких застосовували мінімальну та максимальну норму висіву насіння - 4,0 і 5,5 млн/га, Кее вирощування ячменю ярого за норми висіву насіння 5,0 млн/га зростав відповідно на 3,8 і 7,0 \%.

Розрахунки біоенергетичної ефективності вирощування ячменю ярого, залежно від впливу позакореневих підживлень, свідчать про високу ефективність цього чинника. Найвищим Кее був на варіантах позакореневих підживлень сумішшю комплексного добрива Кристалону особливого 3 біопрепаратом «Агро ЕМ». Порівняно 3 контролем (без проведення підживлень) він зростав на 4,2 \%. Достовірної зміни впливу позакореневих підживлень посівів на варіабельність показників біоенергетичної ефективності під час застосування досліджуваних варіантів норми висіву у проведених дослідах не встановлено.

Погодні умови вносили певні корективи щодо впливу досліджуваних варіантів норми висіву та позакореневих підживлень посівів на показники біоенергетичної ефективності вирощування. Разом із тим, в усі роки досліджень формування вищих показників біоенергетичної ефективності вирощування ячменю ярого забезпечувало комплексне проведення підживлень Кристалоном особливим і біопрепаратом «Агро ЕМ» за норми висіву насіння - 5,0 млн насінин/га.

Проведені розрахунки економічної ефективності вирощування ячменю ярого, показали високу ефективність норми висіву 5,0 млн насінин/га, яка полягала у значному збільшенні рівня рентабельності і приросту прибутку порівняно з контрольним варіантом (табл. 2). Незалежно від строків проведення досліджень під час розрахунків економічної ефективності досліджуваних варіантів вирощування використовували закупівельні ціни на зерно і ресурсні матеріали, які існували у 2014 році.

За норми висіву 5,0 млн насінин/га приріст прибутку порівняно 3 контролем становив 225 грн/га $(18,0 \%)$. Рівень рентабельності у цьому варіанті також був найвищий - $45 \%$, що на 3,0 \% вище, ніж на контролі (табл. 2). Значне підвищення економічної ефективності під час проведення сівби нормою висіву 5,0 млн насінин/га забезпечувалося значно вищою вартістю вирощеного зерна 31 га у випадку незначного підвищення витрат на вирощування. 
СІЛЬСЬКЕ ГОСПОДАРСТВО. РОСЛИННИЦТВО

1. Біоенергетична ефективність вирощування ячменю ярого сорту Докучаєвський 15 залежно від впливу норми висіву та позакореневих підживлень посівів у фазу трубкування (середнє за 2012-2014 рр.)

\begin{tabular}{|c|c|c|c|c|c|c|}
\hline \multirow{2}{*}{$\begin{array}{l}\text { Норма висіву, } \\
\text { млн насінин/га }\end{array}$} & \multirow{2}{*}{$\begin{array}{c}\text { Варіант } \\
\text { підживлення }\end{array}$} & \multirow{2}{*}{ 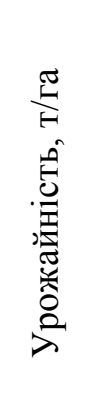 } & \multicolumn{2}{|c|}{$\begin{array}{c}\text { Витрати } \\
\text { непоновлюваної } \\
\text { енергіï, МДж }\end{array}$} & \multirow{2}{*}{ 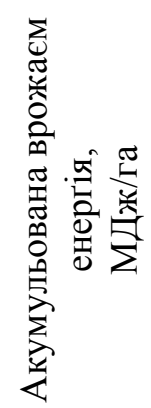 } & \multirow{2}{*}{ Kee } \\
\hline & & & на 1 га & на 1 т зерна & & \\
\hline \multirow{5}{*}{4,0} & $\mathrm{I}^{*}$ & 2,14 & 10740 & 5019 & 35203 & 3,28 \\
\hline & II & 2,24 & 10832 & 4836 & 36848 & 3,40 \\
\hline & III & 2,22 & 10830 & 4878 & 36519 & 3,37 \\
\hline & IV & 2,30 & 10877 & 4729 & 37835 & 3,48 \\
\hline & V & 2,28 & 10875 & 4770 & 37506 & 3,45 \\
\hline \multirow{5}{*}{4,5} & $\mathrm{I}$ & 2,31 & 11135 & 4820 & 38000 & 3,41 \\
\hline & II & 2,40 & 11227 & 4678 & 39480 & 3,52 \\
\hline & III & 2,38 & 11225 & 4716 & 39151 & 3,49 \\
\hline & IV & 2,45 & 11272 & 4601 & 40303 & 3,58 \\
\hline & $\mathrm{V}$ & 2,43 & 11270 & 4638 & 39974 & 3,55 \\
\hline \multirow{5}{*}{5,0} & I & 2,42 & 11525 & 4762 & 39809 & 3,45 \\
\hline & II & 2,50 & 11617 & 4647 & 41125 & 3,54 \\
\hline & III & 2,48 & 11615 & 4683 & 40796 & 3,51 \\
\hline & IV & 2,54 & 11662 & 4591 & 41783 & 3,58 \\
\hline & $\mathrm{V}$ & 2,52 & 11660 & 4627 & 41454 & 3,56 \\
\hline \multirow{5}{*}{5,5} & I & 2,37 & 11920 & 5030 & 38987 & 3,27 \\
\hline & II & 2,41 & 12012 & 4984 & 39645 & 3,30 \\
\hline & III & 2,39 & 12010 & 5025 & 39316 & 3,27 \\
\hline & IV & 2,44 & 12057 & 4941 & 40138 & 3,33 \\
\hline & $\mathrm{V}$ & 2,42 & 12055 & 4981 & 39809 & 3,30 \\
\hline \multirow{4}{*}{$\begin{array}{c}\text { Середнє за нормою } \\
\text { висіву }\end{array}$} & 4,0 & 2,24 & 10831 & 4835 & 36848 & 3,40 \\
\hline & 4,5 & 2,39 & 11926 & 4697 & 39316 & 3,50 \\
\hline & 5,0 & 2,49 & 11616 & 4665 & 40961 & 3,53 \\
\hline & 5,5 & 2,41 & 12010 & 4983 & 39645 & 3,30 \\
\hline \multirow{5}{*}{$\begin{array}{c}\text { Середнє за } \\
\text { підживленнями }\end{array}$} & $\mathrm{I}$ & 2,31 & 11330 & 4906 & 38000 & 3,35 \\
\hline & II & 2,39 & 11422 & 4780 & 39316 & 3,44 \\
\hline & III & 2,37 & 11420 & 4818 & 38987 & 3,41 \\
\hline & IV & 2,43 & 11467 & 4719 & 39974 & 3,49 \\
\hline & $\mathrm{V}$ & 2,41 & 11465 & 4757 & 39645 & 3,46 \\
\hline \multicolumn{2}{|c|}{ Середнє по досліду } & 2,38 & 11421 & 4796 & 39184 & 3,43 \\
\hline
\end{tabular}

Позначення: * - контроль досліду; варіанти досліду: I - без проведення підживлень; II - «Кристалон особливий»; III - «Реаком»; IV - «Кристалон» + «Агро ЕM»; V - «Реаком» + «Агро ЕМ». 
СІЛЬСЬКЕ ГОСПОДАРСТВО. РОСЛИННИЦТВО

2. Економічна ефективність вирощування ячменю ярого сорту Докучаєвський 15 залежно від впливу норми висіву та позакореневих підживлень посівів у фазу трубкування (середнс за 2012-2014 рp.)

\begin{tabular}{|c|c|c|c|c|c|c|c|}
\hline $\begin{array}{c}\text { Норма висіву, } \\
\text { млн/га }\end{array}$ & $\begin{array}{c}\text { Варіанти } \\
\text { підживлень }\end{array}$ & 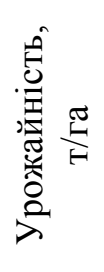 & 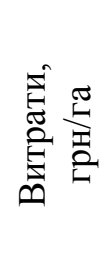 & 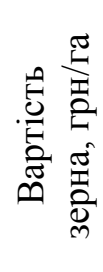 & 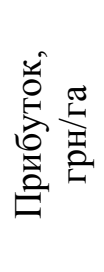 & 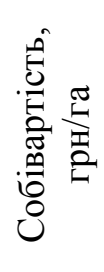 & 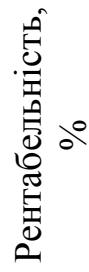 \\
\hline \multirow{5}{*}{4,0} & $\mathrm{I}^{*}$ & 2,14 & 2932 & 4066 & 1134 & 1370 & 39 \\
\hline & II & 2,24 & 2996 & 4256 & 1260 & 1338 & 42 \\
\hline & III & 2,22 & 3003 & 4218 & 1215 & 1353 & 41 \\
\hline & IV & 2,30 & 3051 & 4370 & 1319 & 1327 & 43 \\
\hline & $\mathrm{V}$ & 2,28 & 3058 & 4332 & 1274 & 1341 & 42 \\
\hline \multirow{5}{*}{4,5} & I & 2,31 & 3057 & 4389 & 1332 & 1323 & 44 \\
\hline & II & 2,40 & 3121 & 4560 & 1439 & 1300 & 46 \\
\hline & III & 2,38 & 3128 & 4522 & 1394 & 1314 & 45 \\
\hline & IV & 2,45 & 3176 & 4655 & 1479 & 1296 & 47 \\
\hline & $\mathrm{V}$ & 2,43 & 3183 & 4617 & 1434 & 1310 & 45 \\
\hline \multirow{5}{*}{5,0} & I & 2,42 & 3182 & 4598 & 1416 & 1315 & 45 \\
\hline & II & 2,50 & 3246 & 4750 & 1504 & 1298 & 46 \\
\hline & III & 2,48 & 3253 & 4712 & 1459 & 1312 & 45 \\
\hline & IV & 2,54 & 3301 & 4826 & 1525 & 1300 & 46 \\
\hline & $\mathrm{V}$ & 2,52 & 3308 & 4788 & 1480 & 1313 & 45 \\
\hline \multirow{5}{*}{5,5} & I & 2,37 & 3307 & 4503 & 1196 & 1395 & 36 \\
\hline & II & 2,41 & 3371 & 4579 & 1208 & 1399 & 36 \\
\hline & III & 2,39 & 3378 & 4541 & 1163 & 1413 & 34 \\
\hline & IV & 2,44 & 3426 & 4636 & 1210 & 1404 & 35 \\
\hline & $\mathrm{V}$ & 2,42 & 3433 & 4598 & 1165 & 1419 & 34 \\
\hline \multirow{4}{*}{$\begin{array}{c}\text { Середнє за } \\
\text { нормою висіву }\end{array}$} & 4,0 & 2,24 & 3008 & 4256 & 1248 & 1343 & 42 \\
\hline & 4,5 & 2,39 & 3133 & 4541 & 1408 & 1311 & 45 \\
\hline & 5,0 & 2,49 & 3258 & 4731 & 1473 & 1308 & 45 \\
\hline & 5,5 & 2,41 & 3383 & 4579 & 1196 & 1404 & 35 \\
\hline \multirow{5}{*}{$\begin{array}{c}\text { Середнє за } \\
\text { підживленнями }\end{array}$} & I & 2,31 & 3120 & 4389 & 1269 & 1351 & 41 \\
\hline & II & 2,39 & 3184 & 4541 & 1357 & 1332 & 43 \\
\hline & III & 2,37 & 3191 & 4503 & 1312 & 1346 & 41 \\
\hline & IV & 2,43 & 3239 & 4617 & 1378 & 1333 & 43 \\
\hline & $\mathrm{V}$ & 2,41 & 3246 & 4579 & 1333 & 1347 & 41 \\
\hline \multicolumn{2}{|c|}{ Середнє по досліду } & 2,38 & 3196 & 4527 & 1331 & 1342 & 42 \\
\hline
\end{tabular}

Позначення: * - контроль досліду; варіанти досліду: I - без проведення підживлень; II - «Кристалон особливий»; III - «Реаком»; IV - «Кристалон» + «Агро ЕМ»; V - «Реаком» + «Агро ЕМ».

3 точки зору економічної ефективності, кращою нормою висіву у проведеному досліді була 5,0 млн насінин/га. У цьому варіанті собівартість була найнижчою - 1308 грн/т, а рівень рентабельності найвищим - $45 \%$.

У сучасних умовах важливо враховувати економічні аспекти інтенсифікації технології з використанням хімічних засобів. 3 ростом цін на мінеральні добрива витрати на виробництво одиниці додаткової продукції можуть бути економічно не виправданими, а безсистемне застосування добрив збільшує витрати на виробництво, погіршує екологічний стан навколишнього середовища.

Розрахунки економічної ефективності показали позитивний ефект підживлень посівів ячменю ярого полімерними добривами. У забезпеченні приросту чистого прибутку кращим був варіант 
спільного застосування «Кристалону» особливого та біопрепарату «Агро ЕМ». Приріст прибутку на цьому варіанті порівняно з контролем (без підживлень) зростав на 109 грн/га (8,6 \%).

Висновок. Найвища врожайність та кращі показники біоенергетичної та економічної ефективності вирощування ячменю ярого сорту Докучаєвський 15 відзначено на варіантах норми висіву 5,0 млн насінин/га після підживлень посівів сумішшю «Кристалону» особливого разом 3 біо-

\section{БІБЛІОГРАФІЯ}

1. Бозолова Е. И. Методика биоэнергетической оценки технологии производства продукции растениеводства / Е. И. Бозолова, Е. В. Глинка. М. : Колос, 1983. -45 c.

2. Горбачова О. Ю. Біоенергетична оцінка ресурсозберігаючої технології вирощування сільськогосподарських культур в умовах степової зони УРСР / О. Ю. Горбачова, М. В. Орешкін // Вісн. с.-г. науки. - 1988. - №9. - С. 28-33.

3. Доспехов Б. А. Методика полевого опыта (с основами статистической обработки результатов исследований) / Б. А. Доспехов. - М. : Агропромиздат, 1985. - $305 \mathrm{c}$.

4. Методические указания для подготовки и написания дипломных проектов (работ по экономической и энергетической оценке результатов исследований) / [сост. В. П. Мартьянов]. Х., 1996. - $30 \mathrm{c}$.

5. Стрижова Ф. М. Биоэнергетическая и экономическая эффективность производства зерна сортов яровой пшеницы / Ф. М. Стрижова // Вестник Алтайск. гос. аграр. ун-та. - Серия «Агрономия». - Барнаул, 2012. - №3. - С. 5-7.

6. Терехов А. И. Экономические проблемы развития производства проса / А. И. Терехов // препаратом «Агро ЕМ», що дає підстави рекомендувати ці варіанти для поширення у виробництво.

У середньому за три роки досліджень оптимізація норми висіву та підживлень посівів ячменю ярого сорту Докучаєвський 15 у фазу трубкування сумішшю «Кристалону» і «Агро ЕМ» забезпечувало одержання прибутку на рівні 1525 грн/га, що на 391 грн/га (34,5 \%) більше, ніж на контрольному варіанті.

ВАСХНИЛ ВНИИ зернобобовых и крупяных культур. - Орел, 2001. - С. 3-7.

7. Томащівський 3. М. Продуктивність озимого жита залежно від обробітку грунту і удобрення в умовах Полісся України / 3. М. Томашівський, А. П. Білітюк, А. І. Макарук : [зб. наук. пр. Інституту землеробства УААН]. - К. : Нора-Прінт, 1999. - Вип. 3. - С. 3-8.

8. Ториков В. Е. Нормы и сроки посева зерновых / В. Е. Ториков // Зерновые культуры. 1993. - №1. - C. 26-28.

9. Фатыхов И. Ш. Озимая пшеница в адаптивном земледелии Среднего Предуралья : монография / И. Ш. Фатыхов, Л. А. Толканова ; под ред. И. Ш. Фатыхова. - Ижевск : РИО ФГОУ ВПО «Ижевская ГСХА», 2005. - 156 с.

10. Шоль В. В. Повышение экономической и биоэнергетической эффективности производства высококачественного зерна озимой пшеницы (по материалам сельскохозяйственных предприятий Краснодарского края) : дисс. на соиск. уч. степени к. экон. н. : 08.00.05 / Владимир Владимирович Шоль. - Краснодар, 2001. - 218 с. - (Кубанский гос. аграр. ун-т). 